\title{
Research Paper Economic analysis of growth and instability of coffee in India
}

\section{- Abdul Baqi Ahmadzai and Baljinder Kaur Sidana}

See end of the paper for authors' affiliations

Correspondence to :

Abdul Baqi Ahmadzai

Department of Economics and Sociology, College of Basic Sciences and Humanities, Punjab Agricultural University, Ludhiana (Punjab) India Email: baqi08498@gmail. com

\section{Paper History :}

Received : 18.10.2019;

Revised : 05.02.2020;

Accepted : 12.02 .2020
ABSTRACT : Coffee is a widely consumed non-alcoholic beverage prepared from coffee beans and it is the largest and widely traded tropical agricultural commodity in the world. The present study was conducted to examine growth and instability of coffee in India from 1995-96 to 2016-17 and utilizes the compound growth rate and Cuddy-della valle index to work out the growth rate and instability, respectively. The results revealed that non-traditional areas showed the highest growth rate in area and production of Arabica coffee. In case of Robusta coffee, growth rate in area was the highest in Karnataka during all the periods. At the same time, it also registered the highest instability in area, production and yield of total coffee. The climatic events and supply shocks remain the real threat to the development of a balanced market and sustainable conditions for the Indian coffee economy. Government and financial institution should take appropriate steps to increase the credit facility to the growers, which will increase the production of coffee all over India and will help the country to face competition in the international market in the present globalized era.

KEY WORDS : Growth rate, Cuddy-della valle index, Arabica coffee, Robusta coffee

How To Cite This PAper : Ahmadzai, Abdul Baqi and Sidana, Baljinder Kaur (2020). Economic analysis of growth and instability of coffee in India. Internat. Res. J. Agric. Eco. \& Stat., 11 (1) : 29-35, DOI : 10.15740/ HAS/IRJAES/11.1/29-35. Copyright@2020:HindAgri-Horticultural Society. 